\title{
Jurist-Diction
}

Volume 4 No. 5 September 202

\section{Alternatif Model Kerjasama Build Operate Transfer Pada Pengelolaan Rest Area Jalan Tol}

\author{
Radhian Fiqi Sayoga \\ Radhianfiqi27@gmail.com \\ Universitas Airlangga
}

How to cite:

Radhian Fiqi Sayoga,

'Alternatif Model Kerjasama

Build Operate Transfer Pada

Pengelolaan Rest Area Jalan

Tol' (2021) Vol. 4 No. 5 Jurist-

Diction.

Histori artikel:

Submit 15 Juli 2021;

Diterima 15 Agustus 2021;

Diterbitkan 1 September 2021.

DOI:

10.20473/jd.v4i5.29829

p-ISSN: 2721-8392

e-ISSN: $2655-8297$

\section{Abstract}

The construction of the toll road itself must be based on the Toll Road Concession Agreement which is handled by the Toll Road Regulatory Agency (BPJT) and the Toll Road Business Entity (BUJT). BPJT gives the authority to BUJT to work on toll roads and the section of toll roads. In every toll road construction it is required for BUJT to build a toll road rest area in accordance with what is mandated in Government Regulation No. 15/2005 concerning Toll Roads. BUJT in managing the Rest Area can be done by self-management or by collaborating with partners or investors. In collaborating with partners there are alternative methods of collaboration, namely with Build Operate Transfer and Build Operate Own. This method of cooperation will later be outlined in the Toll Road Rest Management Cooperation Agreement which must refer to Government Regulation Number 15 of 2005 concerning toll roads and Minister of Public Works and Public Housing Regulation No.1 / PRT / M / 2017 Regarding Procedures for Implementing Agency Procurement Business for concession of toll roads and refers to the legal requirements of the agreement.

Keywords: Toll Road Concession; Build Operate Transfer; Toll Road Rest Management Agreement.

\section{Abstrak}

Pembangunan jalan tol sendiri harus berdasar pada Perjanjian Pengusahaan Jalan Tol yang ditantangani oleh Badan Pengatur Jalan Tol (BPJT) dan Badan Usaha Jalan Tol (BUJT). BPJT memberi kewenangan kepada BUJT untuk mengusahaakan jalan tol dan ruas jalan tol. Dalam setiap pembangunan Jalan Tol di haruskan bagi BUJT untuk membangun Rest Area jalan tol sesuai dengan apa yang diamanatkan dalam Peraturan Pemerintah Nomor 15 Tahun 2005 Tentang Jalan Tol. BUJT dalam melakukan Pengelolaan Rest Area tersebut dapat dilakukan dengan swakelola maupun dengan cara melakukan kerjasama dengan mitra atau investor. Dalam melakukan kerjasama dengan mitra terdapat alternatif metode kerjasama yaitu dengan Build Operate Transfer dan Build Operate Own. Metode kerjasama ini nantinya akan dituangkan dalam Perjanjian Kerjasama Pengelolaan Rest Area Jalan Tol yang harus berpedoman pada Peraturan Pemerintah Nomor 15 Tahun 2005 tentang jalan tol dan Peraturan Menteri Pekerjaan Umum dan Perumahan Rakyat No.1/ PRT/M/2017 Tentang Tata Cara Pelaksanaan Pengadaan Badan Usaha Untuk Pengusahaan Jalan Tol serta mengacu pada syarat sah perjanjian. Kata Kunci: Pengusahaan Jalan Tol; Build Operate Transfer; Perjanjian Pengelolaan Rest Area Jalan Tol. 


\section{Pendahuluan}

Infrastruktur adalah salah satu faktor penggerak ekonomi dari suatu negara. Ketersediaan infrastruktur yang memadai merupakan kunci sukses dalam percepatan pembangunan suatu negara, baik yang menyangkut pembangunan ekonomi maupun sosial. Salah satu contoh infrastruktur yang ada adalah jalan tol.

Pengertian jalan tol menurut Pasal 1 angka 2 PP no. 15 Tahun 2005 Tentang Jalan Tol (selanjutnya disebut "PP Jalan Tol”): “Jalan tol adalah jalan umum yang menjadi bagian sistem jaringan jalan dan sebagai jalan nasional yang penggunaanya diharuskan membayar tol”. Pembangunan jalan tol dilakukan di Indonesia dari tahun pertama kali pada tahun 1975 hingga sekarang. ${ }^{1}$ Pemerintah saat ini sedang gencar membangun jalan tol dengan harapan agar dapat memperlancar lalu lintas yang ada serta meningkatkan distribusi barang dan jasa guna menunjang pertumbuhan ekonomi, meningkatkan pemerataan hasil pembangunan dan keadilan, dan meringankan beban dana pemerintah melalui partisipasi pengguna jalan.

Berdasarkan PP Jalan Tol, Pemerintah dapat memberikan hak konsesi (hak pengusahaan) kepada Badan Usaha Jalan Tol (selanjutnya disebut "BUJT") untuk membangun, mengoperasikan dan memelihara ruas tol tertentu . Dasar perikatan antara Pemerintah dengan BUJT ini dituangkan dalam Perjanjian Pengusahaan Jalan Tol (PPJT) yang ditandatangani oleh Pemerintah Cq. Badan Pengatur Jalan Tol, Kementerian PU dengan BUJT yang ditunjuk.

Sebagai kompensasi atas pengusahaan jalan tol yang dilakukan oleh BUJT, Pemerintah memberikan kewenangan kepada BUJT untuk memungut pendapatan tol dan memperoleh pendapatan usaha lain dari pemasangan iklan, utilitas, maupun pengelolaan rest area di Jalan Tol. Rest area ini sendiri diperuntukkan untuk pengguna jalan tol guna tempat beristirahat.

Dalam pembangunan dan pengelolaan Rest Area ini sendiri, BUJT dapat menerapkan sistem swakelola (atau dikelola sendiri oleh BUJT) ataupun dikerjasamakan dengan Investor yang terpilih sebagai Mitra Kerjasama. Apabila

1 'Sejarah Jalan Tol' (Kementrian Pekerjaan Umum dan Perumahan Rakyat Badan Pengusaha Jalan Tol 2019) <http://bpjt.pu.go.id>, accessed 10 Juni 2019. 
BUJT memilih untuk bekerjasama dengan Mitra untuk pengelolaan Rest Area ini, maka BUJT sebelumnya harus menentukan model kerjasama yang sesuai dengan kebutuhannya. Ada beberapa macam bentuk atau skema kerjasama yang digunakan oleh BUJT, antara lain BOT (Build Operate Transfer) dan BOO (Build Operate Own).

Pada saat ini yang sesuai dengan tujuan kontrak antara BUJT dan investor dalam kerjasama untuk pengelolaan Rest Area Jalan Tol yaitu dengan bentuk kerjasama BOT (Build Operate Transfer) yang juga sering dikenal dengan Bangun Guna Serah (BGS). Hal ini dikarenakan BOT memiliki kerugian dan keuntungan yang masih mampu dihadapi BUJT maupun investor dibandingkan dengan bentuk kerjasama BOO. Berdasarkan PP Nomor 38 Tahun 2008 Tentang Perubahan atas Peraturan Pemerintah Nomor 6 Tahun 2006 Tentang Pengelolaan Barang Milik Negara/Daerah Pasal 1 angka 12, Bangun Guna Serah adalah pemanfaatan barang milik negara/daerah berupa tanah oleh pihak lain dengan cara mendirikan bangunan dan/atau sarana berikut fasilitasnya, kemudian didayagunakan oleh pihak lain tersebut dalam jangka waktu tertentu yang telah disepakati, untuk selanjutnya diserahkan kembali tanah beserta bangunan dan/atau sarana berikut fasilitasnya setelah berakhirnya jangka waktu. Sesuai dengan Peraturan Pemerintah tersebut dapat disimpulkan bahwa Bangun Guna Serah / Build Operate Transfer merupakan bentuk perjanjian kerjasama yang dilakukan antara pemegang hak atas tanah dengan investor, yang menyatakan bahwa pemegang hak atas tanah memberikan hak kepada investor untuk mendirikan bangunan selama masa perjanjian Build Transfer Operate (BOT), dan mengalihkan kepemilikan tersebut kepada pemegang hak atas tanah setelah masa Build Operate Transfer berakhir.

Perjanjian kerjasama Rest Area jalan tol ini mempunyai alternatif model kerjasama yang salah satunya adalah Build Operate Transfer dan didalam jurnal ini akan menjelaskan implementasi dari alternatif model kerjasama Build Operate Transfer dalam perjanjian kerjasama pengelolaan rest area jalan tol tersebut sesuai dengan peraturan perundang-undangan yang berlaku saat ini serta menjelaskan status suatu aset dalam perjanjian kerjasama Rest Area jalan tol sesuai dengan perjanjian kerjasama model Build Operate Transfer. 


\section{Pengertian pengelolaan Rest Area jalan tol}

Jika dilihat dari data milik Komite Nasional Keselamatan Transportasi, terdapat sekitar 25\% dari total jumlah kecelakaan yang disebabkan oleh pengemudi yang kelelahan. ${ }^{2}$ Sedangkan jumlah kecelakaan di Indonesia pada tahun 2015, menurut laporan World Health Organization (WHO) (2016), yaitu 38.279 jiwa atau rata-rata 5 jiwa per jam. ${ }^{3}$ Dari beberapa peristiwa kecelakaan tersebut, pemerintah memutuskan untuk mulai membangun banyak Rest Area di beberapa ruas jalan tol. Hal tersebut juga diamanatkan dalam Pasal 7 ayat 3 PP Jalan Tol, yang dipersyaratkan bahwa pada jalan tol antar kota harus tersedia Tempat Iistirahat dan Pelayanan (Rest Area) untuk kepentingan pengguna jalan.

Rest Area sendiri memiliki arti memiliki arti suatu tempat istirahat yang dilengkapi dengan berbagai fasilitas umum bagi pengguna jalan tol, sehingga baik bagi pengemudi, penumpang, maupun kendaraannya dapat beristirahat untuk sementara hal ini sesuai dengan bunyi Pasal 1 angka 2 Peraturan Menteri Pekerjaan Umum dan Perumahan Rakyat Nomor 10/PRT/M/2018 Tentang Tempat Istirahat dan Pelayanan Pada Jalan Tol.

Rest Area dikelompokkan ke dalam 3 (tiga) tipe sebagai berikut: ${ }^{4}$

1. Rest Area Tipe A, yang paling sedikit harus dilengkapi dengan fasilitas umum meliputi ATM dengan fasilitas isi ulang kartu tol, toilet, klinik kesehatan, bengkel, warung/kios, minimarket, mushola, SPBU, restoran, ruang terbuka hijau, dan sarana tempat parkir.

2. Rest Area Tipe B, yang paling sedikit harus dilengkapi dengan fasilitas umum meliputi ATM dengan fasilitas isi ulang kartu tol, toilet, warung/kios, mushola, restoran, ruang terbuka hijau, dan sarana tempat parkir.

3. Rest Area Tipe C, yang paling sedikit harus dilengkapi dengan fasilitas umum

\footnotetext{
${ }^{2}$ Harlan Pangihutan dan Hendra Hendrawan, 'Model Pengelolaan Tempat Istirahat Pada Jalan Non Tol' (2016), 33 Jurnal Jalan-Jembatan No. 2. [128].

${ }^{3}$ ibid

4 'Melepas Lelah Berkendara saat Menuju ke Kampung Halaman, Pemudik dapat Singgah di Tempat Istirahat Tipe A, Tipe B, dan Tipe C' (Kementrian Pekerjaan Umum dan Perumahan Rakyat Badan Pengatur Jalan Tol 2019) < http://bpjt.pu.go.id> accessed 10 Desember 2019
} 
meliputi toilet, warung/kios, mushola, dan sarana tempat parkir yang bersifat sementara.

Tahapan dalam pengelolaan Rest Area Jalan Tol adalah sebagai berikut: tahapan perencanaan, tahapan pembangunan, tahapan pengoperasian, tahapan pemeliharaan dan tahapan serah terima. Setiap pengelolaan yang dilakukan agar berjalan dengan baik, maka diperlukan evaluasi untuk review hasil implementasi selama pengelolaan itu berlangsung agar dapat dilakukan perbaikan berkelanjutan. Fungsi dari evaluasi adalah untuk mengetahui sejauh mana efisiensi dan efektifitas pengelolaan tempat Rest Area dilaksanakan. Pertanggungjawaban dari seberapa jauh tingkat akuntabilitas dan kemudahan membaca laporan pengelolaan Rest Area dapat dilihat dengan alat bantu yaitu standar pelayanan. Standar pelayanan yang ditetapkan agar optimal dalam proses penilaian dan evaluasi harus bersifat spesifik (spesific), dapat diukur (measurable), dapat dicapai (attainable), realistis (realistic), dan dapat dicapai pada kurun waktu tertentu (timely).

Sesuai dengan penjelasan diatas, dapat disimpulkan bahwa pengelolaan Rest Area jalan tol ialah segala pengawasan proses pelaksanaan kebijakan pada tempat istirahat yang merupakan fasilitas umum bagi pengguna jalan tol dengan melalui beberapa tahapan dan pencapaian tujuan yang baik sesuai dengan peraturan perundang-undangan dan standar pelayanan yang telah ditetapkan secara optimal sehingga pengemudi, penumpang, maupun kendaraannya agar dapat beristirahat dengan nyaman.

\section{Kewenangan atas pengelolaan Rest Area}

Pengelolaan suatu sumber daya pasti akan membutuhkan seseorang atau suatu kelompok yang mengawasi dan juga berperan dalam prosesnya agar sistem tetap terjaga. Pada dasarnya, sesuai dengan ketentuan Pasal 3 PP Jalan Tol dinyatakan bahwa "Wewenang penyelenggaraan jalan tol berada pada Pemerintah.". Wewenang penyelenggaraan jalan tol tersebut meliputi pengaturan, pembinaan, pengusahaan, dan pengawasan. Sebagian dari kewenangan Pemerintah dalam penyelenggaraan jalan tol yang berkaitan dengan pengaturan, pengusahaan dan pengawasan tersebut 
dilaksanakan oleh Badan Pengatur Jalan Tol (BPJT). Hal tersebut sesuai dengan Pasal 3 ayat 3 PP Jalan Tol. Sedangkan untuk Pengusahaan Jalan Tol meliputi kegiatan pendanaan, perencanaan teknis, pelaksanaan konstruksi, pengoperasian dan/atau pemeliharaan, dimana sesuai dengan ketentuan Pasal 19 ayat 2 PP Jalan Tol dilakukan oleh BUJT yang memenuhi persyaratan atau Pemerintah dalam hal jalan tol dimaksud dinilai layak secara ekonomi tetapi belum layak secara finansial.

Sebagai kompensasi atas Pengusahaan Jalan Tol yang dilakukan oleh Badan Usaha Jalan Tol tersebut diatas, Pemerintah memberikan hak dan kewenangan kepada BUJT untuk memungut pendapatan tol dan memperoleh pendapatan usaha lain dengan cara memanfaatkan ruang milik jalan tol untuk pemasangan iklan, utilitas maupun Rest Area di Jalan Tol. Segala hak dan kewenangan Badan Usaha Jalan Tol tersebut lebih rinci dituangkan dalam Perjanjian Pengusahaan Jalan Tol yang ditandatangani oleh Pemerintah Cq. BPJT dengan Badan Usaha Jalan Tol yang ditunjuk. Dengan demikian kewenangan untuk pengelolaan Rest Area di Jalan Tol merupakan kewenangan dari Badan Usaha Jalan Tol, kewenangan ini termasuk kewenangan untuk menentukan metode pengelolaan Rest Area dalam bentuk swakelola (dikelola secara mandiri) atau bekerja sama dengan Investor. Apabila Rest Area dikelola secara mandiri maka dibutuhkan manajemen yang handal dan memiliki pengalaman dibidangnya. Disamping itu, dari segi pendanaan, maka dibutuhkan tambahan investasi untuk perencanaan, pembangunan, pengoperasian dan pemeliharaan Rest Area yang jumlahnya cukup besar dan dapat memberatkan secara finansial (cash flow) Perusahaan. Hal-hal tersebutlah yang melatar belakangi sebagian besar BUJT memilih untuk bekerja sama dengan Investor yang terpilih sebagai Mitra Kerjasama untuk pengelolaan Rest Area ini. Apabila BUJT memilih untuk bekerjasama dengan Mitra untuk pengelolaan Rest Area ini, maka BUJT sebelumnya harus menentukan model kerjasama yang sesuai dengan kebutuhannya.

\section{Jenis Model Kerjasama dalam Pengelolaan Rest Area}

Penulis melakukan studi banding dan observasi tentang pengelolaan Rest Area Jalan Tol di PT Jasamarga Surabaya Mojokerto dan dapat dipastikan bahwa PT 
Jasamarga Surabaya Mojokerto akan menggunakan salah satu dari jenis kerjasama yang ada pada saat akan melakukan kerjasama dengan para pihak lain mengenai pengelolaan Rest Area Jalan Tol. Penulis memastikan hal tersebut dengan cara melakukan wawancara dengan Manager Legal Hukum PT Jasamarga Surabaya Mojokerto. Pengelolaan Rest Area pada ruas jalan tol di wilayah manapun sebagian besar juga menggunakan jenis-jenis dari model kerjasama dibawah ini. Namun, perlu diingat bahwa pemilihan model kerjasama apapun juga tergantung pada kesepakatan para pihak.

Laporan Hasil Wawancara

Hari/Tanggal Pelaksanaan : Senin, 9 September 2019

Waktu Pelaksanaan $\quad: 10.00 \mathrm{WIB}$

Tempat Pelaksanaan : : PT Jasamarga Surabaya Mojokerto

Narasumber

: Rezy Remadhani Putri (Manager Legal Hukum PT Jasamarga Surabaya Mojokerto)

Tema Wawancara

: Metode Kerjasama Pengelolaan Rest Area Jalan Tol

Tujuan Wawancara

: Mengetahui jenis-jenis model kerjasama yang digunakan oleh PT Jasamarga Surabaya Mojokerto serta keuntungan dan kerugiannya baik bagi pihak investor atau pihak Badan Usaha Jalan Tol

Hasil Wawancara

Jenis model kerjasama yang diterapkan oleh Badan Usaha Jalan Tol dalam Pengelolaan Rest Area ini antara lain sebagai berikut:

a. Build Operate Own (BOO)

Build Operate Own merupakan salah satu bentuk kerjasama dimana investor diberikan kewenangan berdasarkan Perjanjian Kerjasama yang dibuat oleh BUJT dengan Mitra yang ditunjuk untuk membangun Rest Area termasuk pengadaan tanah (tambahan tanah yang diperlukan diluar ruang milik jalan tol), pembiayaannya, mengoperasikan dan memelihara Rest Area, serta 
memanfaatkan atau memperoleh pendapatan dari hasil pengelolaan Rest Area sesuai dengan jangka waktu kerjasama, dan setelah jangka waktu kerjasama berakhir infrastruktur dimaksud akan menjadi milik Investor itu sendiri.

1) Keuntungan dan kerugian metode kerjasama ini bagi Badan Usaha Jalan Tol:

a) Keuntungan:

- Pembiayaan ditanggung sepenuhnya oleh Investor;

- Dalam hal dibutuhkan tambahan tanah untuk pembangunan Rest Area di luar ruang milik jalan tol, maka baik proses pengadaan tanah maupun biaya yang timbul sepenuhnya menjadi beban Investor;

- Memperoleh Bagi Hasil dari hasil pengelolaan Rest Area yang dilakukan oleh Investor;

- Meminimalisir potensial resiko yang dapat terjadi, baik dari segi keuangan maupun hukum.

b) Kerugian:

- Setelah jangka waktu kerjasama berakhir, maka tanah dan bangunan Rest Area adalah milik Investor (terkecuali tanah yang merupakan ruang milik jalan tol).

2) Keuntungan dan kerugian metode kerjasama ini bagi Investor :

a) Keuntungan:

- Setelah jangka waktu kerjasama berakhir, maka tanah dan bangunan Rest Area adalah milik Investor (terkecuali tanah yang merupakan ruang milik jalan tol).

c) Kerugian:

- Penutupan akses dari bangunan Rest Area yang telah terbangun ke jalan tol oleh Badan Usaha Jalan Tol.

\section{b. Build Operate Transfer (BOT)}

Build Operate Transfer merupakan salah satu bentuk kerjasama dimana investor diberikan kewenangan berdasarkan Perjanjian Kerjasama yang dibuat oleh Badan Usaha Jalan Tol dengan Mitra yang ditunjuk untuk membangun Rest Area termasuk pengadaan tanah (tambahan tanah yang diperlukan diluar ruang milik jalan tol, hal ini tergantung dari hasil kesepakatan Para Pihak), pembiayaannya, mengoperasikan, dan memelihara Rest Area, memanfaatkan atau memperoleh 
pendapatan dari hasil pengelolaan Rest Area sesuai dengan jangka waktu kerjasama, dan setelah jangka waktu kerjasama berakhir infrastruktur dimaksud beralih/diserah terimakan kepada Badan Usaha Jalan Tol.

1) Keuntungan dan kerugian metode kerjasama ini bagi Badan Usaha Jalan Tol: ${ }^{5}$

a) Keuntungan:

- Pembiayaan ditanggung sepenuhnya oleh Investor;

- Memperoleh Bagi Hasil dan Kompensasi Sewa Lahan dari hasil pengelolaan Rest Area yang dilakukan oleh Investor;

- Pada saat jangka waktu kerjasama berakhir, baik tanah maupun bangunan dimana Rest Area berdiri beralih dan menjadi milik Badan Usaha Jalan Tol.

b) Kerugian:

- Dalam hal dibutuhkan tambahan tanah untuk pembangunan Rest Area di luar ruang milik jalan tol, maka menjadi beban Badan Usaha Jalan Tol;

- Terdapat potensial resiko yang dapat terjadi, baik dari segi keuangan maupun hukum (biaya pengadaan tanah yang tinggi dan/atau adanya gugatan dari warga pada saat pengadaan tanah untuk rest area).

2) Keuntungan dan kerugian metode kerjasama ini bagi Investor:

a) Keuntungan:

- Apabila dibutuhkan tambahan tanah untuk pembangunan Rest Area akan dilakukan dan menjadi beban Badan Usaha Jalan Tol;

- Dalam hal pengadaan tanah dilakukan oleh Badan Usaha Jalan Tol maka dapat meringankan tugas Investor dan mempersingkat proses/ tahapan pengelolaan Rest Area;

- Efisiensi biaya, karena tidak mengeluarkan biaya untuk pengadaan tanah Rest Area.

b) Kerugian:

${ }_{5}$ Maria S.W. Sumardjono, Tanah Dalam Perspektif Hak Ekonomi Sosial dan Budaya (Kompas 2009).[53]. 
Pada saat jangka waktu kerjasama berakhir, baik tanah maupun bangunan dimana Rest Area berdiri beralih dan menjadi milik Badan Usaha Jalan Tol.

Masih belum ada Undang-Undang yang secara khusus mengatur dan memberikan pengertian tentang BOT. Oleh karena itu muncul istilah BOT dan diterjemahkan ke dalam Bahasa Indonesia menjadi Bangun Guna Serah (yang selanjutnya disebut BGS) yang diatur dalam peraturan perundang-undangan. Berikut Peraturan perundang-undangan yang mengatur tentang BGS:

a. Keputusan Menteri Keuangan Republik Indonesia (Kep. Menkeu RI) tertanggal 2 Juni 1995 nomor 258/KMK.04/1995, tentang Perlakuan Pajak Penghasilan Terhadap Pihak-Pihak yang Melakukan Kerjasama dalam Bentuk Perjanjian Bangun Guna Serah (Build Operate and Transfer/BOT) disebutkan bahwa BOT adalah:

"Bentuk perjanjian kerjasama yang dilakukan antara pemegang hak atas tanah dengan investor, yang menyatakan bahwa pemegang hak atas tanah memberikan hak kepada investor untuk mendirikan bangunan selama masa perjanjian bangun guna serah (BOT), dan mengalihkan kepemilikan bangunan tersebut kepada pemegang hak atas tanah setelah masa guna serah berakhir".

b. PP Nomor 38 Tahun 2008 Tentang Perubahan atas PP Nomor 6 Tahun 2006 Tentang Pengelolaan Barang Milik Negara/Daerah pada Pasal 1 angka 2 disebutkan bahwa:

"Bangun Guna Serah (BGS) adalah pemanfaatan tanah milik negara/daerah berupa tanah oleh pihak lain dengan cara mendirikan bangunan dan/atau sarana berikut fasilitasnya, kemudian didayagunakan oleh pihak lain tersebut dalam jangka waktu tertentu yang telah disepakati, untuk selanjutnya diserahkan kembali tanah beserta bangunannya dan/atau sarana berikut fasilitasnya setelah berakhirnya jangka waktu".

c. Peraturan Menteri Negara Badan Usaha Milik Negara Nomor PER-13/ MBU/09/2014 tentang Pedoman Pendayagunaan Aset Tetap Badan Usaha Milik Negara pada Pasal 1 angka 9 disebutkan bahwa:

"Bangun Guna Serah (Build Operate and Transfer/BOT) adalah kerjasama pendayagunaan aktiva tetap berupa tanah milik BUMN oleh pihak lain dengan cara mendirikan bangunan dan/atau sarana berikut fasilitasnya, kemudian didayagunakan oleh pihak lain tersebut dalam jangka waktu tertentu yang 
disepakati, untuk selanjutnya tanah beserta bangunan dan/atau sarana berikut fasilitasnya diserahkan kepada BUMN setelah berakhirnya jangka waktu".

Menurut pengertian-pengertian di atas dapat disimpulkan bahwa BOT atau Bangun Guna Serah merupakan suatu bentuk kerjasama dengan pihak pertama (pemegang hak milik tanah/lahan yaitu instansi Pemerintah) mengikatkan diri kepada pihak lain (investor) untuk menyerahkan dan memberikan hak pengelolaan tanah/lahan yang dikuasai kepada pihak investor guna mendirikan bangunan beserta sarana dan fasilitasnya. Pembiayaan seluruhnya akan dibebankan kepada investor serta menggunakan atau mengusahakan bangunan tersebut untuk jangka waktu sesuai dengan kesepakatan. Jika masa perjanjian BOT telah berakhir maka, investor wajib menyerahkan kembali tanah beserta bangunan dan sarana/fasilitasnya kepada pihak pemilik tanah/lahan. ${ }^{6}$

Berbagai keuntungan maupun kerugian masing-masing model kerjasama yang telah diuraikan oleh Penulis diatas, PT Jasamarga Surabaya Mojokerto dan Badan Usaha Jalan Tol lainnya lebih banyak menerapkan model kerjasama ini dibandingkan model kerjasama Build Operate Own (BOO).

\section{Perjanjian Kerjasama Pengelolaan Rest Area Jalan Tol Surabaya-Mojokerto}

Istilah perjanjian ini muncul dari kata bahasa Inggris yaitu "agreement" dan dalam bahasa Belanda, istilah perjanjian atau persetujuan disebut juga dengan “overeenkomst". ${ }^{7}$ Definisi perjanjian sebagaimana dimaksud Pasal 1313 BW yang terdapat dalam Kitab Undang-Undang Hukum Perdata (Burgerlik Wetboek) 14 dalam Buku III tentang Perikatan: "Suatu perjanjian adalah suatu perbuatan di mana satu orang atau lebih mengikatkan diri terhadap satu orang lain atau lebih”.

Namun dapat disayangkan ada beberapa kelemahan dari pengertian perjanjian yang diatur dalam ketentuan tersebut. Hal ini diperkuat dengan beberapa pendapat ahli hukum dalam buku Mariam Darus Badrulzaman mengenai definisi persetujuan

\footnotetext{
${ }^{6}$ Irawan Soerodjo, Kepastian Hak atas Tanah di Indonesia (Arloka 2003).[59].

${ }^{7}$ Leonora Bakarbessy,[et. al], Buku Ajar Hukum Perikatan (Zifatama Jawara 2010).[12].
} 
yaitu: ${ }^{8}$

a. Definisi ini bersifat sempit karena hanya menunjuk pada perjanjian sepihak, yaitu perjanjian yang hanya mempunyai kewajiban pada satu pihak, sedangkan ada perjanjian yang mengandung hak dan kewajiban pada kedua pihak, seperti perjanjian timbal balik.

b. Definisi ini tidak lengkap karena menunjuk pada perbuatan, seharusnya perbuatan hukum. Perjanjian diadakan dengan tujuan untuk memperoleh akibat hukum, perbuatan yang dilakukan tidak dimaksudkan untuk menciptakan akibat hukum.

Subekti berpendapat bahwa perjanjian adalah suatu peristiwa satu orang saling berjanji dengan orang lainnya untuk melaksanakan suatu hal. Dari peristiwa ini, terwujudnya suatu hubungan antara dua orang tersebut yang dinamakan perikatan. Dalam bentuknya, perjanjian itu berupa suatu rangkaian perkataan yang mengandung janji-janji atau kesanggupan yang diucapkan atau ditulis. ${ }^{9}$ Oleh karena itu, dari beberapa pendapat diatas, penulis dapat menyimpulkan bahwa perjanjian merupakan suatu peristiwa antara dua orang atau lebih saling berjanji dan kemudian terciptalah perikatan antara dua orang atau lebih tersebut untuk melaksanakan suatu hal sesuai dengan segala suatu yang telah disanggupinya.

Suatu perjanjian yang sudah dibuat secara sah berdasarkan ketentuan yang berlaku, maka perjanjian tersebut akan otomatis mengikat bagi semua pihak yang telah menyetujuinya. ${ }^{10}$ Syarat sah suatu perjanjian telah diatur dalam Pasal 1320 BW yang berbunyi

Untuk sahnya suatu perjanjian diperlukan empat syarat:

1. Sepakat untuk mereka yang mengikatkan dirinya;

2. Kecakapan untuk membuat suatu perikatan;

3. Suatu hal tertentu;

4. Suatu sebab yang diperbolehkan.

${ }^{8}$ Mariam Darus Badrulzaman, Hukum Perikatan dalam KUH Perdata Buku Ketiga (Citra Aditya Bakti 2015).[83].

9 Subekti, Hukum Perjanjian (Intermasa 1996).[1].

${ }^{10}$ Irawan Soerodjo, Op.Cit.[24]. 
Perjanjian Kerjasama Pengelolaan Rest Area di Ruas Jalan Tol SurabayaMojokerto pada intinya merupakan salah satu bentuk perikatan yang dibuat oleh PT Jasamarga Surabaya Mojokerto selaku Badan Usaha Jalan Tol dengan Investor/ Mitra yang ditunjuk sebagai dasar untuk kerjasama pengelolaan Rest Area di ruas Jalan Tol Surabaya-Mojokerto. Perjanjian Kerjasama ini pada hakikatnya merupakan Perjanjian pada umumnya yang mengacu pada ketentuan Pasal 1320 BW sebagai syarat sah Perjanjiannya dengan unsur-unsur sebagai berikut:

1. Kesepakatan

Para Pihak dalam Perjanjian Kerjasama ini yakni PT Jasamarga Surabaya Mojokerto dan Investor yang ditunjuk oleh PT Jasamarga Surabaya Mojokerto sepakat untuk membuat dan menandatangani Perjanjian Kerjasama Pengelolaan Rest Area di ruas Jalan Tol Surabaya Mojokerto.

2. Kecakapan/kewenangan Para Pihak

PT Jasamarga Surabaya Mojokerto selaku Pihak Pertama dalam Perjanjian Kerjasama sebagaimana telah diuraikan sebelumnya oleh Penulis telah memenuhi unsur kecapakan/kewenangan untuk menandatangani Perjanjian, karena memegang konsesi untuk pengusahaan jalan tol berdasarkan Perjanjian Pengusahaan Jalan Tol. Sedangkan Investor selaku Pihak Kedua dalam Perjanjian Kerjasama ini adalah Badan Usaha berbentuk PT yang ditunjuk oleh PT Jasamarga Surabaya Mojokerto melalui proses pemilihan mitra yang memenuhi kualifikasi yang ditetapkan.

3. Suatu Hal Tertentu

Dalam Perjanjian Kerjasama ini, obyek yang diperjanjian adalah Pengelolaan Rest Area di ruas Jalan Tol Surabaya-Mojokerto.

4. Causa yang diperbolehkan

Bahwa apa yang diperjanjian dalam Perjanjian Kerjasama ini tidak bertentangan dengan Undang-Undang/Peraturan yang berlaku. Bahkan untuk menjamin pemenuhan Undang-Undang/Peraturan yang berlaku tersebut, Perjanjian Kerjasama dibuat dengan berpedoman pada Peraturan Menteri Nomor 10/PRT/M/2018 tentang Tempat Istirahat dan Pelayanan pada Jalan Tol. 
Secara garis besar Perjanjian Kerjasama dengan menggunakan model kerjasama BOT terbagi dalam tiga tahap yang berlangsung secara prosedural, yaitu: ${ }^{11}$

\section{Tahap Pembangunan}

Pada tahap ini Badan Usaha Jalan Tol yang memiliki kewenangan atas pemanfaatan lahan di ruang milik jalan tol akan menyerahkan tanah yang telah dibebaskan untuk kebutuhan pembangunan Rest Area kepada pihak investor guna pembangunan Rest Area beserta segala fasilitasnya. Sebelum dibangun, Investor wajib membuat gambar bangunan (schematic design) dengan disertai penjelasan secara rinci guna memperoleh persetujuan dari Badan Usaha Jalan Tol. Setelah gambar bangunan (schematic design) disetujui oleh Badan Usaha Jalan Tol, maka Investor wajib menyelesaikan pembangunan Rest Area sesuai dengan jangka waktu yang disepakati dalam Perjanjian Kerjasama. Dalam hal pembangunan telah selesai dilakukan oleh Investor, maka Investor akan mengajukan permohonan untuk mulai operasi. Badan Usaha Jalan Tol akan melakukan pemeriksaan atas hasil pembangunan Rest Area, dan setelah dinyatakan laik fungsi, maka sejak saat itu Investor berhak untuk mulai mengoperasikan Rest Area.

2. Tahap Operasional

Pihak investor berhak mengelola bangunan komersial yang dibangun untuk jangka waktu sesuai dengan yang disepakati dalam Perjanjian Kerjasama. Jangka waktu dalam kerjasama pengusahaan jalan tol sesuai dengan Pasal 9 ayat (3) Peraturan Menteri Pekerjaan Umum dan Perumahan Rakyat Republik Indonesia Nomor 01/PRT/M/2017 Tentang Tata Cara Pelaksanaan Pengadaan Badan Usaha untuk Pengusahaan Jalan Tol yang menyatakan bahwa : "Jangka Waktu kerjasama pengusahaan jalan tol dengan bentuk Bangun Guna Serah tanpa Dukungan Pemerintah adalah paling lama 50 (lima puluh) tahun dan

\footnotetext{
${ }^{11}$ I Gede Abdhi Prabawa, Kajian Hukum Terhadap Perjanjian Build Operate and Transfer (BOT) untuk Melindungi Hak Milik atas Tanah Dalam Rangka Menunjang Sektor Pariwisata (Universitas Brawijaya 2014).[11].
} 
dapat diperpanjang sesuai dengan tingkat kelayakan proyek dan peraturan perundang-undangan.”. Selama jangka waktu pengoperasian ini Investor wajib membayar bagi hasil atas pengelolaan Rest Area serta kompensasi sewa lahan kepada Badan Usaha Jalan Tol. Besaran bagi hasil ditentukan oleh Badan Usaha Jalan Tol dari estimasi pendapatan kotor Badan Usaha Jalan Tol tiap tahun secara berjenjang, yang dituangkan dalam Business Plan Investor pada saat mengikuti proses pemilihan Mitra. Sedangkan kompensasi sewa lahan dihitung berdasarkan nilai NJOP tanah yang di serahkan oleh Badan Usaha Jalan Tol guna pembanguan Rest Area dimaksud. Selama jangka waktu pengoperasian dimaksud, Investor juga memiliki kewajiban untuk memelihara Rest Area agar tetap memenuhi standar pelayanan minimal.

3. Tahap Penyerahan

Setelah jangka waktu operasional berakhir, pihak investor wajib menyerahkan kembali hak pengelolaan tanah dan bangunan komersial diatasnya beserta segala fasilitas kepada pihak Badan Usaha Jalan Tol dalam keadaan dapat dan siap dioperasikan.

Berdasarkan hal-hal yang telah diuraikan diatas oleh Penulis, maka dapat diketahui Pelaksanaan Perjanjian Kerjasama Pengelolaan Rest Area dengan Model Kerjasama Build Operate Transfer (BOT) di ruas Jalan Tol Surabaya-Mojokerto yang dilakukan oleh PT Jasamarga Surabaya Mojokerto dengan Investor/Mitra yang ditunjuk telah sesuai dengan ketentuan perundangundangan yang ada. Dimana Perjanjian Kerjasama Pengelolaan Rest Area yang dibuat telah memenuhi syarat sah-nya perjanjian yang diatur dalam ketentuan Pasal 1320 BW.

Keseluruhan tahapan mulai dari tahap Pembangunan, hingga tahap penyerahan kembali (Transfer) yang diatur dalam Perjanjian Kerjasama Pengelolaan Rest Area telah mengacu pada PP Jalan Tol dan Permen No. 10/PRT/M/2018 tentang Tempat Istirahat dan Pelayanan pada Jalan Tol. Sebagaimana konsep kerjasama dengan sistem Build Operate Transfer (BOT), Badan Usaha Jalan Tol dalam hal ini PT Jasamarga Surabaya Mojokerto telah melaksanakan kewajibannya untuk menyediakan tanah 
bagi investor yang akan membangun Rest Area tersebut. Sedangkan pihak investor hingga saat ini masih memenuhi kewajibannya untuk melakukan pengoperasian dan pemeliharaan Rest Area Jalan Tol Surabaya-Mojokerto dengan jangka waktu Perjanjian sampai dengan tahun yang telah ditentukan.

\section{Objek dalam kerjasama Build Operate Transfer}

Dalam suatu usaha yang berhubungan dengan hukum pasti tidak akan terlepas oleh tiga hal penting seperti objek hukum, subjek hukum, dan juga peristiwa hukum. Hal ini juga berlaku dalam perjanjian kerjasama yang menggunakan model Build Operate Transfer (BOT). Subjek hukum dapat berupa perorangan atau badan hukum publik maupun privat. Sesuai dengan penjelasan pada bab sebelumnya, Perjanjian Kerjasama Build Operate Transfer (BOT) untuk pengelolaan Rest Area Jalan Tol Surabaya Mojokerto terjadi antara PT Jasamarga Surabaya Mojokerto dengan pihak mitra. Sehingga PT Jasamarga Surabaya Mojokerto beserta mitranya merupakan subjek hukum dalam Perjanjian Kerjasama Build Operate Transfer (BOT) ini. ${ }^{12}$

Lalu bagaimana dengan objek hukum?

Sesuai dengan Keputusan Menteri Keuangan Republik Indonesia (Kep. Menkeu RI) tanggal 2 Juni 1995 nomor 258/KMK.04/1995, tentang Perlakuan Pajak Penghasilan Terhadap Pihak-Pihak yang Melakukan Kerjasama dalam Bentuk Perjanjian Bangun Guna Serah (Build Operate and Transfer/BOT) pada dasarnya objek dari Perjanjian Kerjasama Build Operate Transfer (BOT) sendiri mencakup : 1. Tanah

Tanah dalam hal ini adalah tanah yang disediakan oleh Badan Usaha Jalan Tol dalam hal ini PT Jasamarga Surabaya Mojokerto untuk pembangunan Rest Area pada ruas Jalan Tol Surabaya-Mojokerto.

Tanah dimaksud dapat dikategorikan sebagai barang milik negara dalam hal tanah tersebut merupakan bagian dan/atau berada dalam ruang milik jalan tol. Mengapa demikian dan apa yang dimaksud dengan Barang Milik Negara? Definisi Barang

\footnotetext{
${ }^{12}$ Urip Santoso, Hukum Agrarian Kajian Komprehensif cet II (kencana 2013).[197].
} 
Milik Negara berdasarkan Peraturan Pemerintah Nomor: 27 Tahun 2014 tentang Pengelolaan Barang Milik Negara, adalah semua barang yang dibeli atau diperoleh atas beban Anggaran Pendapatan dan Belanja Negara atau berasal dari perolehan lainnya yang sah. Tanah yang berada dalam ruang milik jalan tol yang dimanfaatkan untuk pembangunan Rest Area dikatakan sebagai barang milik negara dikarenakan tanah tersebut dibebaskan oleh Pemerintah dengan mengacu pada peraturan tentang Pengadaan Tanah untuk Kepentingan Umum. Namun disamping itu, ada pula tanah yang dibebaskan mandiri oleh Badan Usaha Jalan Tol diluar ruang milik jalan tol (apabila diperlukan tambahan tanah diluar ruang milik jalan tol) guna kebutuhan pembangunan Rest Area.

2. Bangunan Rest Area berikut fasilitas di dalamnya.

Bangunan Rest Area berikut fasilitas di dalamnya ini dibangun dan disediakan oleh Investor dengan menggunakan dana dari Investor.

\section{Kepemilikan aset sebelum berakhirnya perjanjian kerjasama pengelolaan Rest Area dengan model Build Operate Transfer (BOT)}

Sebagaimana telah diuraikan dalam Bab 3.1 diatas, yang dimaksud dengan Aset dalam Perjanjian Kerjasama Pengelolaan Rest Area dengan Model Build Operate Transfer (BOT) ini mengacu pada objek yang diperjanjikan dalam perjanjian yakni :

1. Tanah; dan

2. Bangunan Rest Area berikut fasilitas di dalamnya.

Adapun status kepemilikan aset sebelum berakhirnya Perjanjian adalah sebagai berikut:

1. Tanah

Dikarenakan tanah untuk pembangunan Rest Area ini ada yang merupakan barang milik negara dan ada sebagian tanah yang dibebaskan sendiri oleh Badan Usaha Jalan Tol, maka hal ini akan menentukan pula status kepemilikan asetnya. Untuk tanah yang berada dalam ruang milik jalan tol yang dikategorikan sebagai barang milik negara, maka status asetnya merupakan milik Pemerintah. Jika 
tanah tersebut secara garis besar digunakan dalam rangka pengusahaan Jalan Tol, maka tanah tersebut berada dalam penguasaan Pengguna Barang dalam hal ini Kementerian Pekerjaan Umum. Kementerian Pekerjaan Umum Cq. BPJT selanjutnya memberikan kewenangan kepada Badan Usaha Jalan Tol untuk memanfaatkan tanah dimaksud melalui PPJT. Sedangkan untuk tanah yang dibebaskan sendiri oleh Badan Usaha Jalan Tol diluar ruang milik jalan tol, maka tanah dimaksud merupakan aset milik Badan Usaha Jalan Tol.

2. Bangunan Rest Area berikut fasilitas di dalamnya.

Bangunan Rest Area berikut fasilitas di dalamnya dibiayai dari dana Investor, oleh karenanya status aset atas bangunan berikut fasilitas di dalamnya tersebut merupakan milik Investor.

\section{Kepemilikan aset setelah berakhirnya perjanjian kerjasama pengelolaan Rest Area dengan model Build Operate Transfer (BOT)}

Adapun status kepemilikan aset setelah berakhirnya Perjanjian adalah sebagai berikut:

1. Tanah

Pada dasarnya dalam Perjanjian Kerjasama Rest Area dengan Model Build Operate Transfer (BOT), setelah jangka waktu berakhir tidak terjadi peralihan hak atas tanah. Dikarenakan dari semula, Mitra sendiri hanya mendapatkan hak untuk memanfaatkan dan menggunakan tanah sesuai dengan waktu yang telah disepakati dalam perjanjian. Namun aset kepemilikan sendiri tetap berada pada Pemerintah (untuk tanah yang merupakan barang milik negara) dan Badan Usaha Jalan Tol (untuk tanah yang dibebaskan sendiri oleh Badan Usaha Jalan Tol diluar ruang milik jalan tol).

Hal ini berarti setelah jangka waktu Perjanjian Kerjasama berakhir maka Mitra tersebut harus menyerahkan kembali penguasan atas seluruh tanah yang digunakan guna pembangunan Rest Area kepada Badan Usaha Jalan Tol selaku pihak yang diberikan kewenangan untuk mengelolanya selama masa konsesi Jalan Tol. 
2. Bangunan Rest Area berikut fasilitas di dalamnya.

Sedangkan untuk bangunan Rest Area berikut fasilitas di dalamnya, ketika jangka waktu Perjanjian Kerjasama Pengelolaan Rest Area dengan Model Build Operate Transfer (BOT) berakhir maka status asetnya yang semula milik Investor akan dialihkan kepada Badan Usaha Jalan Tol.

\section{Kesimpulan}

Jenis model pengelolaan rest area dibagi menjadi dua, yaitu secara swakelola sendiri dan kerjasama dengan mitra. Namun untuk meminimalisir resiko usaha yang dapat terjadi karena kurangnya manajemen yang handal dan belum memiliki pengalaman dibidangnya, BUJT dapat memilih untuk melakukan kerjasama pengelolaan Rest Area dengan investor atau mitra. Model kerjasama dengan mitra pun dibagi menjadi dua yaitu dengan model BOT dan BOO. Perbedaan dari BOT dan BOO adalah adanya proses transfer aset pada BOT saat jangka waktu yang ditentukan telah habis, sedangkan BOO tidak terjadi proses transfer aset sehingga aset akan tetap menjadi milik pihak investor. BUJT maupun investor atau mitra lebih sering menggunakan model kerjasama BOT sebagai bentuk perjanjian dalam proses pengelolaan rest area karena lebih dianggap fair bagi kedua belah pihak dibandingkan dengan model kerjasama BOO. Hal ini dapat diketahui dari keuntungan dan kerugian yang akan didapat oleh pihak BUJT maupun investor dari masing-masing model kerjasama yang telah diuraikan. BUJT telah menggunakan kewenangannya dengan baik dalam melakukan perjanjian dengan pihak investor atau mitra. Hal ini dapat dilihat dengan proses perjanjian kerjasama dalam pengelolaan rest area ini antara pihak BUJT dan pihak investor. Hal-hal yang mendukung adanya kewenangan pihak BUJT telah dilakukan dengan baik adalah dengan berpedoman pada Peraturan Pemerintah Nomor 15 Tahun 2005 Tentang jalan Tol dan Peraturan Menteri Pekerjaan Umum dan Perumahan Rakyat Nomor 01/PRT/M/2017 Tentang Tata Cara Pelaksanaan Pengadaan Badan Usaha Untuk Pengusahaan Jalan Tol serta memenuhi syarat sah suatu perjanjian sesuai dengan ketentuan Pasal 1320 BW. Sesuai dengan Pasal 1320 BW, BUJT telah melakukan 
perjanjian dengan unsur adanya kesepakatan, kecakapan, suatu hal tertentu, dan causa yang diperbolehkan serta sesuai dengan klausul-klausul yang ada. Setelah perjanjian telah dibuat, pihak investor dapat melaksanakan pengelolaan Rest Area tersebut sesuai dengan tahapan-tahapan yang telah ditentukan hingga jangka waktu telah habis. Tiga tahapan yang berlangsung secara prosedural dan harus dilakukan oleh pihak investor sesuai dengan model kerjasama BOT yaitu tahap pembangunan, tahap operasional, sampai dengan tahap penyerahan kembali. Meskipun dalam Peraturan-peraturan yang telah disebutkan dalam bab ini tidak mengatur secara detail bagaimana pelaksanaan Build Operate Transfer (BOT) namun pelaksanaan Perjanjian Kerjasama ini telah mengacu pada konsep BOT itu sendiri seperti pihak BUJT yang telah menyediakan tanah untuk proses pengelolaan Rest Area Jalan Tol dan pihak investor juga harus melakukan kewajibannya dalam proses-proses pembangunan serta operasional sesuai dengan perjanjian yang telah dibuat dan melakukan penyerahan kembali saat jangka waktu perjanjian telah habis.

Objek hukum dalam perjanjian pengelolan Rest Area Jalan Tol terdiri atas tanah dan bangunan Rest Area berikut sarana nya. Aset dalam Perjanjian Kerjasama Pengelolaan Rest Area dengan Model Build Operate Transfer (BOT) ini mengacu pada objek yang diperjanjikan dalam perjanjian. Untuk status kepemilikan tanah beserta bangunan dan sarana diatas tanah tersebut Pada saat sebelum berakhirnya jangka waktu perjanjian pengelolaan Rest Area Jalan Tol dengan model kerjasama BOT tanah yang berada dalam ruang milik jalan tol yang dikategorikan sebagai barang milik negara, maka status asetnya merupakan milik Pemerintah. Jika tanah tersebut secara digunakan dalam rangka pengusahaan Jalan Tol, maka tanah tersebut berada dalam penguasaan Pengguna Barang dalam hal ini Kementerian Pekerjaan Umum Cq. Sedangkan tanah yang dibebaskan oleh Badan Usaha Jalan Tol sendiri dan berada di luar ruang milik jalan tol, maka tanah merupakan aset milik Badan Usaha Jalan Tol. Bangunan Rest Area berikut fasilitas di dalamnya dibangun dengan dana Investor, oleh karena itu status aset atas bangunan berikut fasilitas di dalamnya tersebut merupakan milik Investor. Lalu, jika perjanjian kerjasama pengelolaan Rest Area Jalan Tol dengan model BOT telah berakhir maka, tanah tidak akan berpindah 
tangan karena memang sedari awal hak atas tanah tersebut tidak berpindah, hanya saja pihak mitra diberikan hak untuk mengelola dan membangun Rest Area yang berada diatas tanah tersebut. Sedangkan bangunan dan sarana yang berada diatas tanah tersebut akan dialihkan kepada pemilik tanah tersebut.

\section{Daftar Bacaan}

\section{Buku}

Irawan Soerodjo, Kepastian Hak atas Tanah di Indonesia (Arloka 2003).

Leonora Bakarbessy, [et. al], Buku Ajar Hukum Perikatan (Zifatama Jawara 2010).

Maria S.W. Sumardjono, Tanah Dalam Perspektif Hak Ekonomi Sosial dan Budaya (Kompas 2009).

Mariam Darus Badrulzaman, Hukum Perikatan dalam KUH Perdata Buku Ketiga (Citra Aditya Bakti 2015).

Subekti, Hukum Perjanjian (Intermasa 1996).

Urip Santoso, Hukum Agrarian Kajian Komprehensif, cet II (kencana 2013).

\section{Perundang-undangan}

Burgerlijk Wetboek (BW), terjemahan R.Subekti.

Peraturan Pemerintah no. 15 Tahun 2005 Tentang Jalan Tol (Lembaran Negara Tahun 2005 Nomor 32, Tambahan Lembaran Negara Nomor 4489).

Peraturan Pemerintah no. 38 Tahun 2008 Tentang Perubahan Atas Peraturan Pemerintah Nomor 6 Tahun 2006 Tentang Pengelolaan Barang Milik Negara (Lembaran Negara Republik Indonesia Tahun 2006 Nomor 20, Tambahan Lembaran Negara Republik Indonesia Nomor 4609).

Keputusan Menteri Keuangan Republik Indonesia (Kep. Menkeu RI) tertanggal 2 Juni 1995 nomor 258/KMK.04/1995, tentang Perlakuan Pajak Penghasilan Terhadap Pihak-Pihak yang Melakukan Kerjasama dalam Bentuk Perjanjian Bangun Guna Serah (Build Operate and Transfer/BOT) (Lembaran Negara Tahun 2008 Nomor 78, Tambahan Lembaran Negara Nomor 4855).

Peraturan Menteri Pekerjaan Umum dan Perumahan Rakyat Nomor 10 /PRT/M/ 2018 Tentang Tempat Istirahat dan Pelayanan Pada Jalan Tol. 
Peraturan Menteri Pekerjaan Umum dan Perumahan Rakyat Nomor 1 /PRT/M/ 2017 Tentang Tata Cara Pelaksanaan Pengadaan Badan Usaha Untuk Pengusahaan Jalan Tol.

\section{Jurnal}

Harlan Pangihutan dan Hendra Hendrawan, 'Model Pengelolaan Tempat Istirahat Pada Jalan Non Tol' (2016) 33 Jurnal Jalan-Jembatan No. 2.

I Gede Abdhi Prabawa, 'Kajian Hukum Terhadap Perjanjian Build Operate and Transfer (BOT) untuk Melindungi Hak Milik atas Tanah Dalam Rangka Menunjang Sektor Pariwisata' (2014) Universitas Brawijaya.

\section{Laman}

'Melepas Lelah Berkendara saat Menuju ke Kampung Halaman, Pemudik dapat Singgah di Tempat Istirahat Tipe A, Tipe B, dan Tipe C' (Kementrian Pekerjaan Umum dan Perumahan Rakyat, 2019) <http://bpjt.pu.go.id>.

'Sejarah Jalan Tol' (Kementrian Pekerjaan Umum dan Perumahan Rakyat Badan Pengusaha Jalan Tol, 2019) <http://bpjt.pu.go.id $>$. 